UNITED STATES DEPARTMENT OF THE INTERIOR

GEOLOGICAL SURVEY

\title{
Clinoptilolite resources in the Tushar Mountains west-central Utah
}

By

T. A. Steven and C. G. Cunningham

Open-F1le Report 79-535

Th1s report is preliminary and has not been edited or reviewed for conformity with U.S. Geological Survey standards 
What is clinoptilo1ite 1

Location - 3

General geology 3

Cove Fort Occurrence 7

Three Creeks Reservoir occurrence

Dccurrence near Telluride Power Plant No. 2

Cation exchange capacity 16

Analytical results 17

Acknowledgments 18

References cited - 19

\section{Illustrations}

Figure 1. Index map of the Tushar Mountains area

2, Geologic map of clinoptilolite occurrence and sample localities near Cove Fort Explanation

3. Reconnaissance map of clinoptilolite occurrence near Three Creeks Reservoir 
Clinoptilolite resources in the Tushar Mountains, west-central Utah By

T. A. Steven and C. G. Cunningham

Two potentially economic deposits and one possibly economic deposit of clinoptilolite have been found in the Tushar Mountains of westcentral Utah. All three deposits are near the nonwelded distal ends of rhyolitic ash-flow tuff sheets, and appear to have formed mainly by reaction of glassy volcanic ash with ground water. Avallable data are too few and too preliminary to support tonnage and grade estimates, but scattered samples combined with visual estimates suggest an ultimate resource of about several billion tons. A significant part of this resource may contain rock of 80 percent or more clinoptilolite in deposits easily amenable to open-pit mining. The main dilutants are feldspar, biotite, and quartz phenocrysts and forelgn 11thic rock fragments, many of which possibly could be removed mechanically. Clay minerals seem to be minor constituents in most of the deposits.

\section{What is clinoptilolite?}

Clinoptilolite is a common zeolite that occurs widely in sedimentary and pyroclastic volcanic rocks. Zeolites are crystalline hydrated aluminosilicates of alkall and alkaline earth metals, and form most commonly by the reaction of silicic volcanic glass fragments and pore water (such as ground water, lake water, and ocean water). The spectfic zeolite mineral formed depends largely on the chemical composition of the water involved and on the activity ratio of alkali ions to hydrogen ions. Clinoptilolite commonly forms by reaction of 
volcanic glass with ground water or with relatively dilute lacustrine brines; more strongly saline or alkaline lake waters result in other zeolite species or even authigenic feldspar.

Clinoptilolite has a theoretical composition of $(\mathrm{Na}, \mathrm{K})_{2} \mathrm{O} \cdot \mathrm{Al}_{2} \mathrm{O}_{3}$ $10 \mathrm{SIO}_{2} \cdot 6 \mathrm{H}_{2} \mathrm{O}$, but it forms an 1somorphous compositional series with heulandite by $\mathrm{Ca}$ and $\mathrm{Mg}$ substituting in different degrees for $\mathrm{Na}$ and $\mathrm{K}$, and the actual composition varies considerably. Huelandite is commonly less siliceous than clinoptilolite. Clinoptilolite, as do most zeolite minerals, can gain or lose water and exchange cations without major changes in crystal structure, and thus is espectally amenable to ionexchange reactions. In addition, zeolite crystalline structures contain "holes" of specific dimensions that serve as molecular sieves in trapping other cations--the size of the hole determining which cation or molecule can be trapped. Both the lon-exchange and molecular sleve characteristics have wide industrial applications. Clinopt1lolite has the spectfic property of trapping $\left(\mathrm{NH}_{4}\right)$ Ions, and thereby 18 espectally useful in treating sewage effluents and agricultural waste waters, as well as for other agricultural and Industrial purposes. Clinopt1lolite has been used extensively in Japan, but only to a minor extent in the Untted States. With expanding emphasis on preventing man-made pollution, a much more extensive use of clinoptilolite seems assured in the Unfted States in the future.

Clinoptilolite 18 a relatively common mineral where Tertiary or Quaternary silicic volcanic ash accumulated in a watery environment--a combination found at many places throughout Western UnIted States. A low untt price for clinoptilolite probably will prevall after widespread 
use has been achieved. A major economic consideration, once a sizeable body of good grade material has been Identified therefore, w11l be proximity to a potential market. Mining costs also will be an important economic factor. In this report, we 1dentify 3 potential sources of clinopt1lolite, but leave most of these economic factors for potential developers to consider.

\section{Location}

The Tushar Mountains (f1g. 1) are a major topographic element in the High Plateaus of west-central Utah, and are located along the eastern border of the Great Basin 240 to $290 \mathrm{~km}$ south of Salt Lake City. The mountains are high and in part very rugged and inaccessible. The clinoptilolite deposits we have identifled, however, are either at the northwestern margin of the mountains near Cove Fort (f1g. 2), or near Highway 153 that extends east from Beaver across the mountains to Junction (fIg. 3), and are easily accessible by automobile. General geology

The Tushar Mountains are in the heart of the Marysvale volcanic field and consist chiefly of volcanic or related intrusive rocks. As outlined by Steven, Rowley, and Cunningham (1978), volcanism began 35 to 30 million years (m•y•) ago, and since then and about $21 \mathrm{~m} \cdot \mathrm{y} \cdot$ ago calcalkaline intermediate-composition lavas were erupted from many scattered and In part clustered stratovolcanoes. Coalescing volcaniclastic aprons surrounded the volcanoes and built a widespread volcanlc plateau. Ashflow tuffs were erupted eplsodically through this span of time, some from centers within the Marysvale field, and some from centers to the west and southwest. The resulting volcanic assemblage is exceedingly 


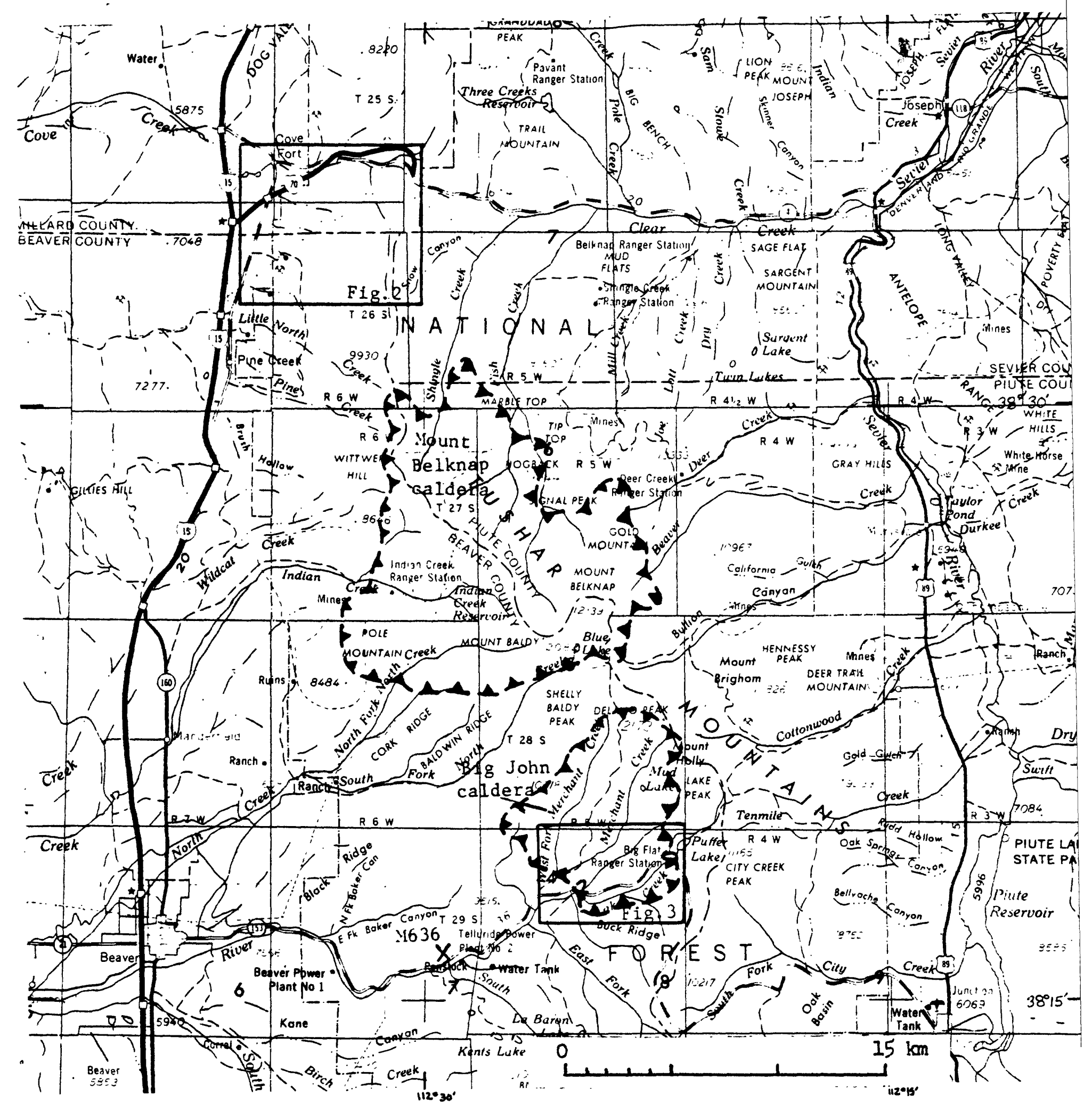

FIgure 1 INDEX MAP OF THE TUSHAR MOUNTAINS AREA, WEST-CENTRAL UTAH, SHOWING LOCATIONS OF FIGURES 2 AND 3, AND OF SAMPLE M636. 


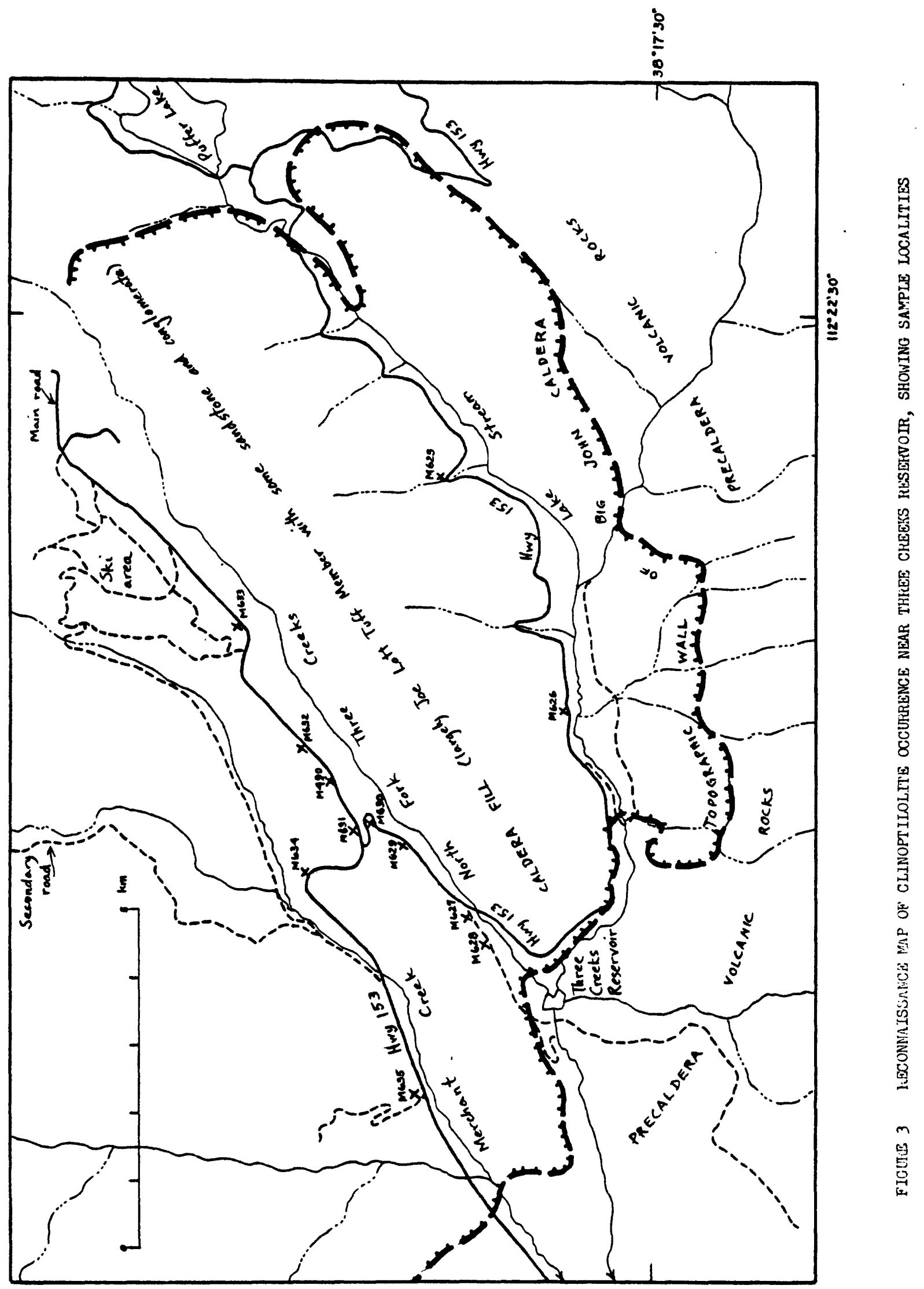


complex, but most detalls of this complexity have little relevance to this report. The area was tectonically stable during this period of volcanism, and only minor local faulting can be documented.

About $21 \mathrm{~m} \cdot \mathrm{y} \cdot$ ago the composition of the erupted volcanic rocks changed from calc-alkaline intermediate-composition to a bimodal assemblage of basalts and high-s1lica alkall rhyolites that was erupted eplsodically until quite recently. The rhyolites were erupted in greatest volume early during this perlod--between 21 and $17 \mathrm{~m} \cdot \mathrm{y} \cdot$ ago-when the Mount Belknap Volcanics accumulated around two concurrently active source areas (Cunningham and Steven, 1977). The western source area was In the northern Tushar Mountalns where the Joe Lott Tuff Member erupted $19 \mathrm{~m} \cdot \mathrm{y} \cdot$ ago and the major Mount Belknap caldera (fIg. 1), approximately $14 \mathrm{~km}$ across, subsided as the source magma chamber was emptled. The Joe Lott Tuff Member spread radially from the caldera and accumulated in low areas on the surrounding volcanic plateau. Bimodal volcanlsm was broadly contemporaneous with Basin-Range block faulting that disrupted the entire Great Basin and High Plateaus in late Cenozolc t1me.

Clinoptilolite deposits formed from slliclc ash-flow tuffs erupted during both the calc-alkalic and the bimodal perfods of activity. The large deposits near Cove Fort (fig. 2) formed in the distal part of an unnamed calc-alkalic ash-flow tuff sheet derived from an unknown source In the Great Basin to the west shortly before $22 \mathrm{~m} \cdot \mathrm{y}$. ago. The deposits near Three Creeks Reservoir In the headwaters of Beaver River (f1g. 3) formed in the marginal part of an accumulation of ash-flow tuffs in the Mount Belknap Volcanfcs, a major rhyolite unft in the bimodal 
assemblage. The possibly important clinoptilolite deposits in the western Tushar Mountains near the Beaver River are near the northern end of a local ash flow sheet that was erupted late during the perfod of calc-alkalic eruptions.

\section{Cove Fort occurrence}

The clinoptilolite occurrence southeast of Cove Fort (fig. 2) 1s near the eastern margin of a sheet of nonwelded ash-flow tuff that passes laterally eastward into tuffaceous sandstone and related sedimentary rocks. The source of the sheet appears to have been in the Great Basin to the west. The zeolitic tuff underlies the $22 \mathrm{~m} \cdot \mathrm{y} \cdot-$ old Osiris Tuff (Fleck and others, 1975, p. 59), a major-ash flow unit to the east and southeast, and overlies in turn the tuff of Albinus Canyon and the $27 \mathrm{~m} \cdot \mathrm{y} \cdot-01 \mathrm{~d}$ Three Creeks Tuff Member of the Bullion Canyon Volcanics (Steven and others, 1977), both derived from sources in the southern Pavant Range east and northeast of figure 1. The zeolitic tuff is cut by a hypabyssal pluton of monzonite that had been exposed by erosion $22 \mathrm{~m} \cdot \mathrm{y}$. ago so that the Osiris Tuff was deposited unconformably across 1t. The zeolitic tuff, therefore, is presumed to have been deposited sometime during the middle of the $5 \mathrm{~m} \cdot \mathrm{y}$. Interval between eruption of the Three Creeks Tuff Member and the Osiris Tuff--perhaps about $24 \mathrm{~m} \cdot \mathrm{y}$. ago. The zeolitic tuff has no known stratigraphic counterparts in the Pavant Range or Tushar Mountains to the northeast, east, and southeast. The area toward 1ts probable source in the Great Basin is too poorly known at present for possible stratigraphic equivalents to be determined. 
The zeolitic tuff is exposed in a series of fault blocks that form a west-extending ridge at the northwest end of the Tushar Mountains (figs. 1 and 2). Away from this spur, the tuff is exposed only in a few low knolls south of Sulphurdale. Stratigraphlcally equivalent tuffaceous sandstones are exposed in roadcuts along highway $\mathrm{I}-70$ at the pass between Cove Creek and Clear Creek (ffg. 1) and In a few natural exposures less than a k1lometer to the east. Thus almost the full known extent of clinoptilolite at the Cove Fort occurrence is shown on figure 2.

The zeolitic rock is a massive white ash-flow tuff $100 \mathrm{~m}$ or more thick. Zeolitized matrix commonly constitutes 80 percent or more of the rock, and the remainder consists of fresh phenocrysts of feldspar, biotite, and quartz, and of Irregularly distributed foreign lithic fragments. Visual estimates suggest that the rock was uniformly altered to clinopt1lolite by diagenet1c processes. Inasmuch as neither the ash-flow tuff nor the related tuffaceous sandstone show evidence of having been deposited in standing water, or that any lake developed in the area after deposition, it is presumed that diagenesis was accomplished by ground water. The result is a compact but soft 11thifled white rock that has a distinctive greasy luster on fresh surfaces. This luster, which can be compared to that on a broken surface of a cake of white laundry soap, is characteristic of zeolitic tuffs.

Qualitative X-ray diffraction studies of the matrix of 5 random samples (localities shown on $f i g .2$ ) of the zeolitic tuff gave the following results: 
78-S-24A Clinoptilolite, major; quartz, significant; clay, minor 78-S-25 Clinoptilolite, major; quartz minor

78-S-27A Clinoptilolite, major. quartz, significant; clay, minor 78-S-27B Clinoptilolite, major; quartz, significant; clay, minor 78-S-28 Clinoptilolite, major; quartz, present; clay, minor Petrographic modes of thin sections from the same samples in percent are the following:

Sample no. Matrix K-spar Plag. Qtz. B1o. Opaq. Lithics

$\begin{array}{llllclll}78-S-24 A & 85 & 3 & 4 & \operatorname{Tr} & 1 & 1 & 6 \\ 78-S-25 & 84 & 7 & 3 & - & 1 & \operatorname{Tr} . & 5 \\ 78-S-27 A & 87 & 3 & 6 & - & 1 & \operatorname{Tr} . & 5 \\ 78-S-27 B & 82 & 6 & 3 & - & 1.5 & \operatorname{Tr} . & 7.5 \\ 78-S-28 & 78 & 12 & 6 & 1 & 1 & \operatorname{Tr} . & 2\end{array}$

The quartz noted in the X-ray diffraction patterns is alpha quartz and probably represents fragments of phenocrysts and some of the residual silica left over from conversion of siliceous glass to clinoptilolite. Much of the diagenetically derived silica seems to have been removed in solution in the generally open system ground water environment of alteration, as the local sparse secondary concentrations of chalcedony are not abundant enough to account for the diagenetically avaflable silica. The feldspar, blotite, and quartz phenocrysts, and possibly the forelgn 1ithic fragments, are sufficiently distinctive in physical properties from the zeolitic matrix that they possibly could be separated mechanically. Diagenetic clay minerals or silica, on the other hand, probably are too finely dispersed in the matrix to be easily separated. 
Although the area of occurrence of the clinoptilolite near Cove Fort is highly faulted ( $f$ Ig. 2), the net result is economically advantageous, Inasmuch as the faulting tended to keep the zeolitic tuff unit near the surface where it could be mined easily. Open-cut mines could be established at many places where virtually no overburden needs to be stripped. Most of these places can be reached readily by short, easily maintained roads. Surface disturbance for development or mining need be minimal.

The main area of exposure of the zeolitic tuff is somewhat more than $3 \mathrm{~km}$ across both $\mathrm{N}-\mathrm{S}$ and $\mathrm{E}-\mathrm{W}$. Outlying areas add to the total area of occurrence. Considering a square block $3 \mathrm{~km}$ across and $100 \mathrm{~m}$ thick, a minimum volume of $9 \times 10^{8}$ cubic meters of zeolitic tuff was computed. Again using a minimal figure of 2.0 for the density of the clinoptilolite-bearing rock, a resource of at least 1.8 billion metric tons is indicated. A metric ton is about the same as a long ton in English units. This specific figure has very little meaning in itself, other than to indicate that a tremendous tonnage of potentially valuable zeolitic tuff exists near Cove Fort, and that large amounts of this are easily avallable. Careful sampling and analysis of many local fault blocks are needed, however, before the true economic potential of the deposits can be established.

Three Creeks Reservoir occurrence

South of their source in the Mount Belknap caldera (fig. 1), ash flows of the Mount Belknap Volcanics accumulated chiefly in a depression marking the earlier Big John caldera. Most of the ash-flow tuffs are slightly to moderately welded and are completely devitrified. Near the 
southern topographic wall of the Big John caldera (fig. 3), the tuffs locally remalned glassy and unwelded, and some of these glassy tuffs subsequently were altered diagenetically to clinoptilolite and montmorillonite. Through 1978, our detailed geologic mapping was limited to the northeastern part of the area shown on figure 3 ; the remainder, including the part with the best-grade clinoptilolite, had been covered in broad reconnalssance only, and detailed geologic relations are poorly known.

The Big John caldera formed in response to eruption of the Delano Peak Tuff Member of the Bullion Canyon Volcanics; the Delano Peak Member has been dated by the $\mathrm{K}-\mathrm{Ar}$ method as about $22 \mathrm{~m} \cdot \mathrm{y} \cdot$ (Steven and others, 1977), the same as the stratigraphically older Osiris Tuff;analytical uncertainties, however, easily permit a million years or more to have intervened. The Big John caldera was partly filled by mafic lava flows shortly after 1t formed, but much of the same area was still a depression several million years later when the $19 \mathrm{~m} \cdot \mathrm{y} \cdot$ old ash flows of the Mount Belknap Volcanics were erupted. Retention of a local depression this long seems unlikely unless it were drained, but to date our reconnalssance has not located the required outlet. A sequence of fluviatile sandstones and conglomerates several tens of meters thick covered the bottom of the depression near its southern margin.

About $19 \mathrm{~m} \cdot \mathrm{y} \cdot$ ago, great pyroclastic eruptions from the Mount Belknap caldera area to the north (fig. 1) spread voluminous crystalpoor ash flows radially outward to accumulate in topographically low areas as the Joe Lott Tuff Member (Steven and others, 1977; Cunningham and Steven, 1977). This member filled the southern part of the Big John 
caldera to depths of $150 \mathrm{~m}$ or more. No evidence was seen to indicate that any of these ash flows were deposited in water, again suggesting that the BIg John depression was drained.

Subsequent smaller-volume eruptions of more crystal-rich ash covered the massive Joe Lott Member with thinner beds of tuff. Although most of these layers appear to have spread as ash flows and to have been deposited subaerially, local exposures of well-bedded water-1aid tuff indicate that local ponds existed at least part of the time.

Whereas most of the Mount Belknap ash-flow tuff in the B1g John caldera is slightly to moderately welded and devitrified, some near the southern margin remained glassy and unwelded. This glassy tuff was chiefly altered by diagenetic processes to clinoptilolite or montmorillonite. The altered tuff was sampled to determine the mineralogy, but no attempt was made at this early stage of the investigations to determine thickness or lateral extent.

Qualitative X-ray diffraction studies of 11 samples of Mount Belknap tuffs near Three Creeks Reservoir (localities shown in figure 3 ) gave the following results: 
M 490 clinoptilolite, major;feldspar and quartz, minor

M 626 clinoptilolite, predominant

M 627 clinopt1lolite, predominant

M 628 clinoptilolite, predominant

M 629 No zeolite, mostly sanidine, albite, and quartz

M 630 clinoptilolite, major

M 631 montmorillonite, predominant

M 632 clinoptilolite, minor; mostly sanidine, albite, and quartz

M 633 No zeolite; mostly sanidine, albite, and quartz

M 634 clinopt1lolite, present; quartz major

M 635 No zeolite; mostly sanidine, albite, and quartz (altered crystal-rich tuff, matrix only)

(altered Joe Lott Member)

(altered Joe Lott Member)

(altered Joe Lott Member)

(devitrifled Joe Lott Member)

(altered crystal-rich tuff, matrix only)

(altered crystal-rich tuff, matrix only)

(devitrified Joe Lott Member)

(devitrified Joe Lott Member)

(devitrified Joe Lott Member)

(devitrifled Joe Lott Member) 
Petrographic modes of thin sections from the more altered of these samples are shown in percent:

Sample

number Matrix K-spar Plag. Qtz. Bio. Pyrox. Opaques Lithics Unit

\begin{tabular}{|c|c|c|c|c|c|c|c|c|c|}
\hline M 490 & 65 & 10 & 7 & 2 & 1 & 2 & 3 & 0 & $x-r$ \\
\hline M 626 & 90 & 1 & .5 & .5 & Tr. & Tr. & $\operatorname{Tr} \cdot$ & 8 & JL \\
\hline M 627 & 96 & 1 & 1 & - & 1 & - & Tr. & 1 & JL \\
\hline M 628 & 87 & 5 & 1 & Tr. & 1 & - & Tr. & 6 & JL \\
\hline M 630 & 78 & 13 & $\operatorname{Tr}$. & $\operatorname{Tr}$ & $\operatorname{Tr}$. & - & $\operatorname{Tr}$ & 8 & $x-r$ \\
\hline M 631 & 81 & T2 & Tr. & - & - & - & 1 & 6 & $x-r$ \\
\hline
\end{tabular}

$1_{x-r}$ Crystal-rich tuff in upper part of Mount Belknap Volcanics

JL Crystal-poor Joe Lott Tuff Member, Mount Belknap Volcanics H1gh-grade clinoptilolite was obtained from 3 samples (M 626, M 627, and $M$ 628) of crystal-poor tuffs of the Joe Lott Member near the Three Creeks Reservolr (fig. 3). The zeolitic matrix in these samples averages more than 90 percent of the rock. M 626 was from near the base of the unit, and M 627 and M 628 from undetermined vertical positions within the main body of the unit. About $4 \mathrm{~km}$ separate the easternmost from the westernmost of these samples, and brief inspection of float and outcrops between these suggest that much of the intervening area is underlain by diagenetically altered tuff of the same general aspect. Moderate-grade clinopt1lolite was determined in samples M 490 and M 630 from crystal-rich layers near the top of the Mount Belknap sequence 3-4 km northeast of the Three Creeks Reservolr (fig. 3). These samples are sufficiently near one another to suggest a potential 
resource in this area, but another nearby sample of the same type of tuff, M 631, consisted largely of montmorillonite. Some of the tuff in this vicinity is well-bedded, indicating deposition in a local pond, so the diagenetic environments here could have varied considerably and have led to heterogeneously altered products.

Samples of the Joe Lott Member peripheral to the area of zeolite occurrence were largely devitrified (M 620, $M 633, M 635$ ) and contain no clinoptilolite or montmorillonite. Diagenesis in the general Three Creeks Reservoir area thus appears to have varied considerably in degree and distribution.

In summary, we can report an area at least $4 \mathrm{~km}$ across near the Three Creeks Reservolr in which high-grade clinopt1lolite has been determined in at least 5 random samples spread over a vertical stratigraphic range of 150 meters or more. The vertical or lateral extent of high grade material has not been determined at any local area, but visual estimates suggest that potentially valuable local concentrations could exist. The area is easily accessible by good roads, and additional testing can be accomplished readily. The tonnage of diagenetically altered tuff in this vicinity is estimated in terms of millions of tons; the percentage of good grade clinoptilolite within this tonnage is unknown but could be substantial.

$$
\text { Occurrence near Telluride Power Plant No. } 2
$$

A layer of soft white relatively crystal-rich ash-flow tuff is exposed on the north slope of the canyon of Beaver River a few kilometers northwest of Telluride Power Plant No. 2 and above a sharp switchback on H1ghway $153(\mathrm{f} f \mathrm{~g} \cdot 1)$. This area had not been mapped 
geologically by us through 1978, and our knowledge of the geology is minimal. The tuff appears to be stratigraphically high in the section of calc-alkalic volcanic rocks comprising this part of the Marysvale volcanic fleld, but its precise stratigraphic position or lateral correlatives are not known.

Two grab samples taken at the switchback (M 636, M 636A) contain significant clinoptilolite according to X-ray diffraction patterns. A petrographic mode of a thin section of one of these samples showed 75 percent zeolftic matrix, 12 percent feldspar phenocrysts, trace to 1 percent opaque, blotite, quartz, and pyroxene phenocrysts, and 11 percent lithic rock fragments.

Certainly the clinoptilolite resource potential of this ash-flow tuff sheet merits more investigation.

\section{Cation exchange capacity}

The cation exchange capacity of six zeolite samples was determined by Harry Starkey of the U.S. Geological Survey, and is tabulated below. The procedure followed is described in Starkey (1964). Samples were crushed and soaked overnight at room temperature in an ammonium chloride solution. The amount of ammonia adsorbed on the sample was determined by distillation. The results are reported in millequivalents per 100 grams of sample which is a standard format. The results indicate that four of the six samples tested are of average quality, and two samples (M 626 and $M$ 628) are of excellent quality. 
Sample Number

\begin{tabular}{|c|c|c|}
\hline & \multicolumn{2}{|c|}{ (milliequivalents/100 grams) } \\
\hline M 490 & 62.1 & Crystal-rich tuff \\
\hline M 626 & 146.4 & Joe Lott Tuff Member \\
\hline M 628 & $117 \cdot 3$ & Joe Lott Tuff Member \\
\hline $78-S-24 A$ & 54.2 & \\
\hline $78-S-27 B$ & $63.5\rangle$ & Cove Fort occurrence \\
\hline $78-S-28 B$ & 62.6 & \\
\hline
\end{tabular}

Exchange capacity

Three

Creeks

Reservoir

occurrence

The six samples of clinoptilolite-bearing tuff tested for exchange capacity were also analyzed for their contents of $\mathrm{CaO}, \mathrm{Na}_{2} \mathrm{O}$, and $\mathrm{K}_{2} \mathrm{O}$. The results tabulated below fall into 3 groups that correspond to the different tuffs sampled. Sample M 490 of a crystal-rich tuff near the top of the Mount Belknap Volcanics near Three Creeks Reservolr is relatively high in $\mathrm{CaO}, \mathrm{N}_{2} \mathrm{O}$, and $\mathrm{K}_{2} \mathrm{O}$ for a total of 8.06 percent. The underlying Joe Lott Tuff Member (M 626, M 628) is relatively low in these constituents (5.75-5.78 percent), and of this total, CaO is predominant. The zeolitic tuff near Cove Fort, on the other hand, tends to be high in total $\mathrm{CaO}, \mathrm{Na}_{2} \mathrm{O}$, and $\mathrm{K}_{2} \mathrm{O}$ content $(6.59-8.65$, percent), with $\mathrm{K}_{2} \mathrm{O}$ predominating over $\mathrm{CaO}$ and $\mathrm{Na}_{2} \mathrm{O}$. Comparing these results with the exchange capacity data, it can be seen that the tuffs with high CaO content and relatively low $\mathrm{Na}_{2} \mathrm{O}$ and $\mathrm{K}_{2} \mathrm{O}$ contents ( $M 626, M$ 628) have the highest cation exchange capacity. The more sodic and potassic tuffs have about average exchange capacity 
Sample Content (percent) Sample

number $\mathrm{CaO} \quad \mathrm{Na}_{2} \mathrm{O} \quad \mathrm{K}_{2} \mathrm{O} \quad$ Total description

$\left.\begin{array}{lllllll}\text { M } 490 & 3.25 & 1.75 & 3.06 & 8.06 & \text { Crysta1-rich tuff } \\ \text { M } 626 & 3.00 & 0.81 & 1.94 & 5.75 & \text { Joe Lott Tuff Member } \\ \text { M } 628 & 3.31 & 0.34 & 2.13 & 5.78 & \text { Joe Lott Tuff Member }\end{array}\right\} \begin{aligned} & \text { Threeks } \\ & \text { Rervoir } \\ & \text { occurrence }\end{aligned}$

$\left.\begin{array}{lllll}78-S-24 A & 2.38 & 0.79 & 3.41 & 6.59 \\ 78-S-27 B & 1.69 & 1.46 & 5.50 & 8.65 \\ 78-S-28 & 1.81 & 1.63 & 4.94 & 8.38\end{array}\right\}$ Cove Fort occurrence

Acknowledgments

$X$-ray diffraction determinations for this report were made by Michael G. Nelson, and petrographic modes by James G. Brophy. Harry Starkey measured the cation exchange capacity of $s 1 x$ of the samples, and Violet M. Merritt analyzed the same samples for $\mathrm{CaO}, \mathrm{Na}_{2} \mathrm{O}$, and $\mathrm{K}_{2} \mathrm{O}$. 


\section{References cited}

Cunningham, C. G., and Steven, T. A., 1977, Mount Belknap and RedH111s calderas and associated rocks, Marysvale volcanic field, westcentral Utah: U.S. Geological Survey Open-f1le Report 77-568.

Fleck, R. J., Anderson, J. J., and Rowley, P. D., 1975, Chronology of mid-Tertiary volcanism in the HIgh Plateaus region of Utah: Geological Society of America Special Paper 160, p. 53-60.

Starkey, H. C., 1964, Determination of the Ion-exchange capac1ty of a zeolit1c tuff: U.S. Geological Survey Prof. Paper 475-D, p. 93D95.

Steven, T. A., Cunningham, C. G., Naeser, C. W., and Mehnert, H. H., 1977, Revised stratigraphy and radiometric ages of volcanic rocks and mineral deposits in the Marysvale area, west-central Utah: U.S. Geological Survey Open-file Report 77-679.

Steven, T. A., Rowley, P. D., and Cunningham, C. G., 1978, Geology of the Marysvale volcanic field, west-central Utah: Brigham Young University Geology Studies, v. 25, pt.1, p. 67-70. 


\section{Figure 2}

\section{(MAP AT BACK)}

EXPLANATION

Qa

ALLUVIAL DEPOSITS (QUATERNARY)

Q1s

LANDSLIDE DEBRIS (QUATERNARY)

Ty

VOLCANIC UNITS YOUNGER THAN THE ZEOLITIC TUFF (QUATERNARY

AND TERTIARY)--Includes basalt flows, Joe Lott Tuff Member of Mount Belknap Volcanics, and Osiris Tuff

TI MONZONITE INTRUSIVE ROCK (TERTIARY)

Tzt ZEOLITIC TUFF UNIT (TERTIARY)

To VOLCANIC UNITS OLDER THAN THE ZEOLITIC TUFF (TERTIARY)--

Includes tuff of Albinus Canyon, Three Creeks Tuff Member, volcanics of Wales Canyon, and volcanics of Dog Valley, all of Bullion Canyon Volcanics

TMzs UNDIVIDED TERTIARY AND MESOZOIC SEDIMENTARY ROCKS

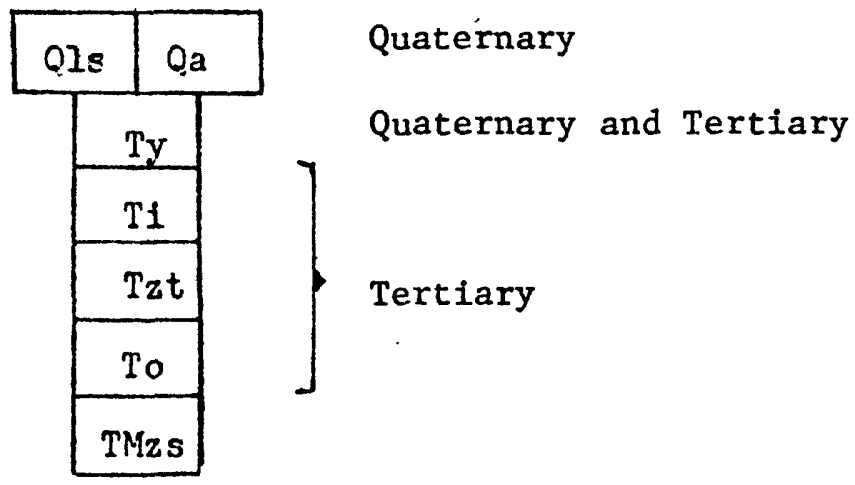

FAULT--Bar and ball on downthrown side. Dotted where covered

CONTACT 